\title{
Institutional innovation of EU's foreign and security policy: Big leap for EU's strategic actorness or much ADO about nothing?
}

\author{
Monika Sus ${ }^{1}$
}

(C) Macmillan Publishers Ltd., part of Springer Nature 2017

\begin{abstract}
The analysis takes stock of the recent institutional developments within European Union's foreign and security policy and examines to what extent the Union has managed to overcome some of the substantial hinders in the way for its evolvement into a strategic actor. The paper scrutinizes the impact of the recent dynamics within EU's foreign and security policy on Union's strategic actorness within three benchmarks: (1) the capacity to extract resources from various EU's foreign and security stakeholders, (2) the ability to relate these resources to EU's objectives and to express them within a general strategic narrative, and (3) the implementation of the strategy in the light of changes in the global arena. The article shows that these three benchmarks have been advanced and now it is up to the Member States to engage with it and to make the leap towards a strategic actor possible.
\end{abstract}

Keywords Strategic actorness · European Union global strategy · Strategic autonomy $\cdot$ High representative

\section{Introduction}

The extent to which the EU weighs in as a strategic actor in the global arena has been a subject of lively debate among scholars since the beginnings of European Political Cooperation, the ancestor of the Common Foreign and Security Policy (CFSP). Over the decades, scholars have been eager to determine what kind of actor or power the EU is or is not, should or should not be-civilian or normative power, trade power, transformative power, etc. (Cross 2011; Aggestam 2008; Orbie 2006; Hyde-Price 2006; Manners 2002). Their ideas and conceptualization of the EU's

Monika Sus

sus@hertie-school.org

1 Hertie School of Governance, Friedrichstraße 180, 10117 Berlin, Germany 
power and actorness have changed in accordance with geopolitical developments, such as the end of the Cold War, as well as with structural developments of the Union itself in relation to its institutional framework, new policies, and decisionmaking processes. However, regardless how one might perceive the characteristics of the EU's international actorness, by creating the Common Foreign and Security Policy with its military component-Common Security and Defence Policy (CSDP), the EU has become a unique actor in international relations and entered a space dominated by nation-states. Despite the criticism about the deficient coherence and low effectiveness of Union's foreign policy, the EU has recently managed to, i.e. successfully close the negotiations of the nuclear deal with Iran, issue sanctions on Russia because of its aggression on Ukraine. As scholars note 'decades of co-operation and increased institutionalization made the Union a respected foreign policy actor with an impact on the international scene' (Pomorska and Vanhoonacker 2016, 215). Others argue that due to its and distinctive civilmilitary profile, the Union is far better position conceptually than many traditional world powers to deal with challenges of the twenty-first century (Howorth 2009).

Against this backdrop, this paper pays attention to the institutional developments within the European Union linked with the implementation of the Treaty of Lisbon and the development of the A Global Strategy for the European Union's Foreign and Security Policy (EUGS) and asks the question in which way and to what extent do they embrace the EU's strategic actorness. Drawing on Toje's understanding of actorness as a yardstick by which the process of change in EU foreign policy can be monitored (2008, 204), the article argues that the recent changes on EU's institutional level push its strategic actorness forward. Being aware of the shortcomings of the application of 'actorness' as a concept (Drieskens 2017), this paper first defines what constitutes strategic actorness and then applies a framework for investigating the extent to which it has been advanced due to the institutional developments. Inspired by institutions-related criteria which the EU needs to fulfil in order to become a strategic actor (Smith and Xie 2010, 434; Allen and Smith 2010), this article scrutinizes the dynamics within three benchmarks: (1) the capacity to extract resources from various EU's foreign and security stakeholders, (2) the ability to relate these resources to EU's objectives and to express them within a general strategic narrative, and (3) the implementation of the strategy in the light of changes in the global arena. The analysis examines to what extent the Union meets these benchmarks that constitute focal elements of EU's actorness and has managed to overcome some of the substantial hinders in the way for its evolvement into a strategic actor.

This paper focuses on the recent decade to examine how and to what extent institutional developments within the European Union have fed into or embraced the concept of strategic actorness. It aims to make a twofold contribution to current scholarship. First, the goal is to contribute to the lively debate about EU actorness in the world (Drieskens 2017) by focusing attention on the strategic dimension of its 'capacity to behave actively and deliberately in relation to other actors in the international system' (Sjöstedt 1977, 16). Secondly, it aims to advance the understanding of the overall impact of the recent dynamics within the area of EU foreign and security policy by perceiving the EUGS and the institutional 
developments linked to it as one element of strategic actorness (Smith 2017; Tocci 2016, 2017; Howorth 2016; Biscop 2016; Sus 2016).

The article proceeds as follows. First, the notion of strategic actorness is examined and the basic assumptions underpinning the concept are laid out. Then, external and internal factors that impact the evolvement of EU's towards a strategic actor are briefly discussed. The following section pays attention to the three components that mark out the changes in the EU's role: the capacity to combine resources of various EU foreign and security stakeholders; the ability to relate these resources to European objectives and to express them within a general strategic narrative (EUGS) and the implementation of its strategy in the light of changes in the global arena. This third benchmark focuses on the defence component of the Union's development as an external power since this aspect sheds most light on the execution of the EUGS. The conclusion summarizes the main findings and reflects on the question to what extent the EU evolved towards a strategic actor due to the institutional changes. In a final step, questions resulting from the analysis provide a perspective for further research.

\section{Strategic actorness as a concept}

Together with the concept of power, and sometimes even perceived as a synonym of it, actorness has become one of the most prominent models for analysing the EU's functioning in international relations (Drieskens 2017; Engelbrekt and Hallenberg 2007; Bretherton and Vogler 2006). Consequently, several interpretations are available to describe this notion. Sjösted, whose definition probably counts as the standard, defined actorness as the 'capacity to behave actively and deliberately in relations to other actors in the international system' $(1977,16)$. Two other seminal definitions link actorness with the ability to exert influence (Allen and Smith 1990) and to shape the perceptions and expectations of others (Hill 1993). These reflexions imply that there is a process of conscious, purposeful strategy in active pursuit of long-term objectives and of gaining the necessary means to that end (Biscop 2009, 19-20). Reflecting on existing definitions, this paper understands the EU's strategic actorness as the Union's ability to react to global challenges by defining the interests that guide the formulation of its aims, which then become a basis for developing and implementing the instruments needed to fulfil these interest-led targets.

The literature offers a variety of concepts for assessing strategic actorness (Drieskens 2017). One pioneer approach, developed by Cosgrove-Sacks and Twichett, stipulated three elements of the capacity of an international organization to act globally: its autonomous decision-making power, its impact in international relations, and the significance attached to the organization by its members (1970, 12-14). A few decades later, Jupille and Caporaso (1998) put forward the most complex operationalization of the EU's actorness, which received a lot of scholarly attention (Niemann and Bretherton 2013). They identified four criteria to determine actorness, namely recognition, authority, autonomy, and cohesion. Recognition relates to the external perception of the EU's willingness and capability to act. Authority is defined as the legal competence to act on a given issue at stake; thus in 
the case of the EU, it is the formal authority delegated by the Member States to the EU institutions as well as the informal authority of some institutions developed through substantial expertise. The notion of autonomy concerns the distinctiveness of the EU's institutions and policy during international negotiations. Last and finally, cohesion forms the most complex criterion and has several dimensions. The authors distinguish 'value cohesion' as the degree of common basic goals, 'tactical cohesion' as the availability of methods to make diverging goals fit one another, 'procedural cohesion' as the degree of consensus concerning how to deal with conflicting issues, and 'output cohesion' as the degree of success in formulating common policies, regardless of substantive and procedural agreement.

While recognizing the importance of the external perceptions of the EU's willingness and capability to act as a strategic actor, this paper focuses on the institutional dimension of the Union's strategic actorness. Drawing on the existing literature, we can assume that the EU needs to fulfil three criteria linked to its institutional framework. It has to (1) develop a capacity to combine the resources of various EU foreign and security stakeholders, such as other EU institutions and the Member States; (2) relate these resources to EU objectives and express them within a general strategic narrative; and (3) adapt its aims, resources allocation, and strategy to changes in the global arena (Smith and Xie 2010, 434; Allen and Smith 2010).

As far as the second benchmark is concerned, the analysis perceives the EUGS as the strategic document most similar to a traditional understanding of a grand strategic narrative or a grand strategy, and hence, it will focus on the development of this plan. That is why the third criterion will be slightly adjusted to the current institutional dynamics in the EU-the EUGS published in June 2016 is being implemented and it is too soon to talk about its adaptation. Thus, the focus of the analyses within the third benchmark will lie on the application of the most pressing proposals of the EUGS in the light of global changes - to the development of the defence component of the Union's foreign and security policy. In this field, the execution of the EUGS happens to the greatest extent. Moreover, a European strategic approach requires the appropriate integration of the military component (Howorth 2010, 465), which it has not managed to develop for years.

Before evaluating the EU's institutional framework along the three aforementioned benchmarks, it is necessary to gain a brief overview of both the internal and external background for the Union's evolution to become a strategic actor.

\section{Background beyond the dynamics of the EU's foreign and security policy}

Drawing on the understanding put forward by Toje, along which actorness changes when a shift occurs $(2008,213)$, external and internal factors that presumably instigated and influenced the change in EU actorness will be briefly discussed here. In a first step, three groups of factors are identified.

Global changes generate the first group. As Falkner argues, 'the outlook for Europe's external relations has never looked so uncertain in the post-cold war era' (2017, 389). Indeed, the ongoing shifts in the EU's external environment comprise a long list: the growing Daesh threat, war in Syria, refugee and migration waves close 
to EU borders, consolidation of the authoritarian regime in Turkey, Russia's revisionist ambitions in its immediate neighbourhood, as illustrated by the war at Ukrainian territory and the annexation of Crimea in 2014, perhaps also the precariousness of US President Donald Trump's policy and his waning commitment to the transatlantic partnership. The latter reflects a tendency that already initiated by the administration of Barack Obama, who started the slow disengagement from Europe. The US security umbrella, without which the European project might have fallen apart, is shrinking (Merlingen 2012, 13). Hence, the EU's strategic emancipation from the USA is due to happen, especially if one takes into account the above-mentioned challenges facing the Union in its neighbourhood and beyond.

The second group of factors results from internal dynamics that might have instigated the change towards more strategic actorness. As was the case with the external factors, the word 'uncertain' also seems to be a buzzword in relation to the internal challenges. One could argue that, over the last decade, it might very well have been the most common adjective used to describe the dynamics within the European project. Political and economic stability, liberal order based on the rule of law, pluralism and the absence of major conflicts on EU territory are not taken for granted anymore. Among all political and economic turmoil that has pulled the Union apart and divided it internally in the last decade-the economic crisis and ongoing fiscal instability of some Member States, the refugee and migration crisis, growing political polarization, illiberal tendencies across the EU, the growing danger of domestic terrorism-Brexit delivered the coup de grâce. The unthinkable has become thinkable. After the British referendum, even an exit of a country from the EU is no longer taboo. As the High Representative of the EU for Foreign Affairs and Security Policy, Federica Mogherini (HR), said during the presentation of the Global Strategy, by the UK's decision, 'The purpose, even the existence, of our Union is being questioned' (EEAS 2016, 2).

The third group also relates to internal changes that constitute the background for the dynamics within EU foreign and security policy and derives from the institutional changes brought by the Treaty of Lisbon. The post-Lisbon foreign policy architecture, with two newcomers - the new-look high representative (office filled by Catherine Ashton from 1 December 2009 till 1 November 2014 who has been replaced by Federica Mogherini) and the European External Action Service (EEAS), was predominantly supposed to enhance the coherence of various instruments of the EU's external action and to provide effective leadership able to coordinate the national diplomacies and the Brussels machinery. The right to put forward her own proposals, the double role in the European Commission (as the Vice-President) and in the Council (as the chairman of the FAC), the diplomatic service with almost 4200 officials at her disposal, make the post-Lisbon HR a potentially powerful actor (EEAS 2016, 4). ${ }^{1}$ Although the HR has to respect the decisive competence of the national leaders and act within the boundaries they set, her uniquely multidimensional position makes her able to link various dimensions of EU external action and to contribute thereby to its coherence. As for the EEAS, despite hard beginnings and battels for power and influence among the EU

\footnotetext{
1 The role of the HR is set out mainly in Art 18, Art 27 and Art 34 of the Treaty of Lisbon.
} 
institutions (mainly the European Commission and the Council) and the national diplomacies, the Service is now clearly out of the infancy period and it is slowly maturing (Novotná 2017, 179). The resources of the headquarter in Brussels and the first hands on the ground expertise of 139 delegations in the third countries frame the Service as a natural centre of strategic thinking in EU foreign policy. While this capability of the EEAS is still not fully fledged, as will be presented in the subsequent section, there have been advances in this regard and the EUGS constitutes an illustrative example.

From both the realist and the constructivist perspective, crises play a distinctive role either as catalysts, as in the case of the former, or as a formative experience, as in the case of the latter. Both forms can lead to policy change. The assessment of the way in which the presented shifts influence the evolution of the EU towards a role as strategic actor is mixed. On the one hand, scholars point out that recent transformations towards more disorder in the regional and global arenas as well as the disintegration dynamics on the European continent have weakened Europe's influence and standing on the global arena. At the same time, however, these shifts have made the EU more conscious about the salience of the need to develop itself into a more strategic actor with the ability to influence the environment and not to be caught by surprise by events such as the annexation of Crimea or the migration and refugee crisis. The idea beyond the institutional changes introduced by the Lisbon Treaty was to enhance consistency of EU external action. The new actors, HR and the EEAS, might not have become a game changer in terms of making the EU foreign policy fully coherent and effective. However, they provide a framework for facilitating more coherent foreign policy making by combining resources and supporting the implementation of the decisions which is crucial in times of uncertainty and global challenges. Thus, one can argue that the window of opportunity (or even a window of necessity) for the EU to evolve and become a more strategic actor in the international arena has opened. The next section deals with the question whether the EU indeed has a chance to seize the moment and use the crisis as a trigger for its own strategic development.

\section{Providing a framework for the EU's strategic transformation}

This section scrutinizes the impact of the recent dynamics within the EU foreign and security policy on EU's strategic actorness along the framework presented above.

\section{Capacities to combine the resources of $\mathrm{EU}$ foreign policy stakeholders}

The first benchmark against which the move towards more strategic actorness is assessed as the capacity to combine the resources of various EU foreign and security stakeholders, i.e. other EU institutions and the Member States.

This capacity to pool resources and bring coherence is embedded in the role of the High Representative. The HR has a unique institutional position that combines functions in four institutions: in the European Council by participating in the summits, in the Council by chairing the Foreign Affairs Council, in the European 
Commission as Vice-President and as head of the EEAS. Moreover, due to her multiple responsibilities, such as delivering proposals for CFSP actions, conducting these policies, putting them into effect, and ensuring their implementation, as well as representing the EU in all matters relating to this policy domain and liaising with the European Parliament (Art. 18, 26-29, 38 TEU and 14, 18, 24 EU), the HR has quite a distinctive role to play. Since the Member States have kept their 'traditionally dominant role' (Moravcisk 1999, 295) as decision-makers, the HR is highly dependent upon the support of the national capitals with regard to processes of implementation. Nonetheless, unique position of the HR across the institutions predestines the incumbent to combine resources coming from various foreign policy stakeholders. The drafting process of the EU Global Strategy illustrates a successful example of such resource pooling. From the very beginning, Mogherini expressed her willingness to make it a collective endeavour by calling it 'A strategy that is not drawn up in a closet by a select few, but through a broad process that involves the Member States and EU institutions as well as the foreign policy community including academia and think tanks, the media and civil society' (2015). In the end, she succeeded to involve the Member States (via COREPER, Foreign Affairs Council's meetings, the EU Military Committee and the National Contact Points at national Foreign Ministries), the European Parliament (especially the AFET Committee), the European Commission (in her role as the Vice-President and the chair of the Commissioners' Group on External Action comprising of commissioners dealing with trade, neighbourhood and enlargement negotiations, trade, development, humanitarian aid, climate action and energy, transport and migration). With regard to her role as Vice-President of the Commission, she was backed up by the undertakings of President Juncker, who prioritized security issues from the beginning of this term (Junker 2014; Juncker 2016). Mogherini and her team also managed to activate as the broad academic and expert community working in the area of European foreign policy. Within the outreach process that facilitated the debate on the strategy, numerous discussions, seminars and workshops took place between October 2015 and April 2016 across Europe and over 50 papers written by academics and experts from all around the world fed into the drafting process. (EUISS 2016). The outcome of this multidimensional process is a strategy for which is much more comprehensive in scope by combining various elements of EU external action and rich in details than any strategic document of the Union with regard to external action.

This paper does not argue that the HR and her team managed to integrate positions and priorities of every single stakeholder. Yet it is notable that the involvement of various actors into the drafting process of the EU's arguable most strategic document has been unprecedented and can thus be perceived as a step towards developing EU strategic actorness. As Robert Cooper, one of the authors of the European Security Strategy (ESS) from 2003, noticed, comparing the drafting process of the EUGS to the one of ESS, that 'this is being done very differently now, and I think that is right. Mrs Mogherini seems to have created quite elaborate structures for debate and involving the national Governments all along (...). If you want to produce big changes in a big lumbering institution, you need to build up a consensus within the Member States and the institution itself, and you do that by 
having the debate' (Cooper 2015). Furthermore, one can argue that through the open and consultative method a nucleus of a European public sphere in security has developed, which also can be viewed as an important element of the Union's actorness (Hoffmann 2000).

However, the element of strategic thinking would definitely improve with better linking of the resources of EU institutions and Member States. Recent attempts to develop the strategic capabilities across EU institutions are still not sufficient yet interesting - in 2017 the European Commission was actively engaged in foresight thinking and developed two proposals with alternative futures for the general scenarios for the overall development of the European Union (European Commission 2017a, b, c) and for the enhancement of its security and defence policy (European Commission 2017a). However, integrating global trend analyses and solid and comprehensive foresight thinking into the EU's foreign policy planning, particularly in the light of the proliferation of challenge in this field would enhance the EU's evolvement towards more strategic actor. The Strategic Planning Division within the EEAS, the inter-institutional European Strategy and Policy Analysis System, the European Political Strategy Centre in the European Commission, Long Term Trends Team at the Cabinet of the Secretary General in the European Parliament and various actors dealing with foresight studies from Member States could combine resources in order to better tackle future challenges. At the same time, the strategic planning of the EU's external action should involve regular evaluation of the Union's performance in various dimensions of its international involvement. As it will be presented in the next section, a first step in this direction was made by the evaluation of the EUGS after 1 year of its implementation.

\section{Developing a strategic narrative}

The second benchmark of strategic actorness implies the necessity of linking existing resources to the EU's objectives and of expressing them in a form of a general strategic narrative. A strategy that defines the goals and ends of a state or of an organization constitutes a fundamental element of strategic actorness.

In fact, the Union was never short on strategies, having developed many of them over the last decades. However, it missed the 'grand one' until 2003, when Javier Solana and his team made a first attempt to fill the gap with the European Security Strategy (ESS). Notably, this document was intended, not as a strategy, but merely as a remedy to overcome the differences between the Member States over the support for USA attack on Iraq. In the same vein, the review of the ESS published in 2009 also did not have the character of a strategic document, as it did not address all the elements of physical security, economic prosperity and value projection. A discussion among the Member States and other EU foreign policy stakeholders took place to determine whether a fully fledged strategy was needed or not, but since there was no unity among them, the European Council invited the HR only to assess the impact of changes in the global environment (European Council 2013, 4). While Ashton did not pick up the ball, her successor did and she seized the opportunity to convince the Member States of the need for a new strategic document. Already during her hearing in the European Parliament in October 2014, Mogherini referred 
to the European Council's request for a strategic assessment by saying that she 'greatly welcome the mandate' and signalled that the 'joint process of strategic reflection could eventually lead the way to a new European Security Strategy' (Mogherini 2014, 6). In the course of the following months, she delivered a preliminary strategic assessment (EEAS 2015) and thereby paved her way to obtain a clear mandate from the European Council to develop a new strategy (European Council 2015). After an inclusive drafting process (cf. the previous section of this paper), in June 2016 has been announced.

The EUGS has received mixed assessments. Some scholars criticize the lack of strategy and of clarity in terms of prioritization and the linking of existing instruments with the Union's objectives (Smith 2017, 511-515). Others point out that the strategy clearly identifies EU objectives and interests and, by moving away from the utopian vision of democratization as a leading attitude in its relations with most of its neighbours, puts forward the concept of 'principled pragmatism' that recognizes the limits of the Union's transformative power (Biscop 2016). Moreover, by reintroducing the idea of 'strategic autonomy', the EUGS has managed to give momentum to security and defence policy (Dijskra 2016, 370) while leaving the concrete implementation to sub-strategies. Another aspect of the EUGS that may be seen as bringing new quality into EU strategic actorness is the 'living' character of the document with its regular evaluations-for instance, in the summer of 2017, the report 'Implementing the European Union Global Strategy. Year 1' was published (EEAS 2017a, b).

Therefore, despite its shortcomings, the EUGS seems to be the most fitting document produced in Brussels to count as a grand strategy as defined by HydePrice. He argued that such a strategy results from a political act that entails calibrating means and ends, capabilities and objectives on the basis of an understanding of the structural context within which the actor is situated (HydePrice 2004, 46). Thus, it can be argued that the EU Global Strategy makes a step towards the enhancement of EU strategic actorness. How big that step will be depends on how well the implementation of its records proceeds, and in this process, the Member States have the decision-making power.

\section{Adapting the strategy in the light of global changes}

The third and the final benchmark of the EU's involvement towards a more strategic actor is linked to its ability to adapt and implement its strategy in the light of a changing environment. This criterion will be reflected with regard to the recent dynamics happening in the field of European security, and since in this area the Union seems to have an urgent need for revision, and thus, the materialization of the EUGS is arguable most visibly in this field.

Taking into account rising uncertainties and the unpredictability of the USA's commitment to the transatlantic partnership as well as the growing number of military conflicts along the EU's borders, the label of an economic giant and a military worm started to bother the EU. Already in 2013, the European Council made security and defence one of its priorities. Since then, the topic has been on the agenda of every summit (with the exception of the special meetings dedicated to 
specific issues, e.g. Brexit) and the heads of state and governments repeatedly called for action in this field (European Council 2013; Council of the EU 2015). In a similar vein, the national foreign ministers claimed that 'the Council is more than ever committed to further strengthening CSDP and enhancing the EU's ability to act as a security provider' (Council of the EU 2015, 4). European security and defence was also announced to be one of the top priorities for the European Commission led by President Juncker, who fuelled a heated debate by proposing the creation of an European Army (Keating 2015) and then calling for creating a 'fully-fledged European Defence Union by 2025' (Juncker 2017). At the same time, public support for more integration of security and defence policy has been constantly above $70 \%$ since 1999 (European Commission Public Opinion 2017) and the support for more common foreign policy has been enjoyed a similar popularity. The strong support of European citizens towards further integration in this field combined with a perception of shared threats - according to the recent Pew Research Centre's study, $74 \%$ Europeans are afraid of ISIS, $64 \%$ of climate change and 54\% of cyberattacks (Poushter and Manevich 2017, 7)_-deliver a clear signal in the direction of policymakers to enhance cooperation regarding foreign, security and defence policies. Against this backdrop, the advancement of European security capabilities became one of the leading narratives during the drafting process of the EU and proved to be a subject of further sub-strategies meant to implement the EUGS's provisions.

Recognizing the comprehensiveness of proposals aimed at enhancing security cooperation which were put forward in the HR's 'Implementation Plan on Security and Defence' (Council of the EU 2016) and in Juncker's 'European Defence Action Plan' (European Commission 2016), this paper takes a special note of three initiatives which may contribute significantly to embracing of EU strategic actorness. Firstly, the permanent structured cooperation (PESCO), called by Juncker the 'Sleeping Beauty of the Lisbon Treaty' (2017), is now awaked. Presently, the criteria for permitting groups of like-minded and capable Member States to take European defence to the next level and put forward more advanced projects are being discussed and in September there were already 30 project proposals at the table ${ }^{2}$. The preparations for its activation not only caused a heated debate among Member States about the criteria for launching and joining PESCO, but they also made the national policy-makers to put their commitment to stronger CSDP on the table (von der Leyen 2017). The Council will decide on the criteria for these 'coalitions of the willing' and establish PESCO by the end of 2017 (EEAS 2017a). First projects are to be launched in January 2018. PESCO was stipulated by Art. 42.6 of the Treaty of Lisbon, yet it remained a dead letter for almost a decade. Its activation might become a game changer leading to deeper integration in EU's foreign and security policy and thereby contribute to the evolvement of the Union towards a more strategic actor. As experts argue in the reference to PESCO 'This is a much-needed step forward, given that the defence landscape within the EU remains extremely diverse and it is becoming increasingly difficult to reach internal consensus to launch timely and effective interventions outside EU borders, especially high-end military operations' (Marrone et al. 2017).

\footnotetext{
$\overline{2}$ The information was obtained in an interview an official from EEAS, 15 September 2017.
} 
Secondly, the European Commission arrived at the table and for the first time in the history of the European integration decided to engage in the field of security and defence by launching a European Defence Fund (EDF) (European Commission 2017b). Almost 600 million euros until 2020 and then 1.5 billion euros each year shall be allocated for technological innovation, defence research and technology (Ibid). The aim of this fund is to contribute to the economy of scale, to reduce the risk of duplication of investments in the defence sector between the Member States as well as to foster interoperability between European armies by standardization of equipment. This money allocated for the EFD is only a small share if one compares it to the total defence spending of all EU Member States, yet the added value of EFD lies in the possibility to identify innovative endeavours that are directly linked to common EU's interests (Koenig and Hass 2017, 13). Thus, the launch of EDF marks the first time that common EU budget will be used to strengthen joint defence capabilities and that makes it potentially a significant leap towards strategic actorness. However, it remains to be seen to what extent the European Commission will indeed be able to offer incentives for the Member States to pool their defence resources and to invest in joint projects in order to achieve the desirable economy of scale. As experts rightly noted, it would require placing collective efficiency concerns higher than national sovereignty considerations, which is a questionable alternative in the light of re-nationalization tendencies in some Member States.

A third idea put forward in the EUGS and picked up by the Council is the Coordinated Annual Review on Defence (CARD) which will be carried out by the European Defence Agency. This mechanism aims at monitoring national defence spending in order to identify possibilities for cooperation and pooling resources. Systematic sharing of information between Member States on their defence planning will aid in delivering joint capabilities and enhancing defence cooperation among EU countries. However, since this instrument is voluntary it remains an open question which Member States will be willing to report to the EDA their spending and planning's. A CARD trial run has been launched in autumn 2017, and the European Defence Agency is expected to present a report to the Council in the second half of 2018. Potentially, CARD could help to avoid duplications of military spending and open new avenues for multilateral cooperation between the Member States. Yet, as in the case of EDF, the commitment of the national leaders is the key. If they join forces and let the EDA monitor their defence expenditures and are willing to seize the opportunities for cooperation, CARD can contribute considerably to the EU's strategic actorness. At the same time, the Head of States and Governments during the summit of the European Council in October 2017 highlighted the need for all three projects to be mutually reinforcing in order to enhance incentives for defence cooperation among EU countries (European Council 2017). The exact ideas for the mutual reinforcement are still up for debate among the Member States.

Despite the above-mentioned developments in the field of security and defence, the credible threat of the use of force coming from the EU is still much ahead but taking into account the dynamics of the recent changes in this field as well as the external pressures it cannot be ruled out in the next decade. At the end, "the onus of 
improving European security lies first of all in European hands' (European Commission 2017a, b, c, 7).

\section{Conclusions}

In 2010, Bendiek and Kramer argued that the EU's claim about pursuing strategic foreign policy was backed up at purely rhetorical level $(2010,463)$. In other words, there was no strategic actorness of the EU. If we follow Smith and take as a reference point for our evaluation of EU actorness, the comparison of the Union's ability to coordinate its foreign policy instruments and to project external power 10, 30 or 50 years ago, then clearly the EU strategic actorness has advanced (2011, 160). While the findings of this paper do not provide a positive proof for a European foreign policy being coherently guided by a comprehensive strategy, yet the analysis shows that the changes to evolve into a strategic actor are evident. The impact of the new institutional framework introduced in the Treaty of Lisbon on the embracement of EU strategic actorness proved to be reformative. This paper's analysis showed that all three elements of EU strategic actorness (the threefold capacity to pool together resources and to transform the polyphone of interests of different stakeholders, to develop a comprehensive strategy for EU foreign and security policy and to implement it in terms of the EU's security and military dimension) have been advanced over the recent decade. Naturally, the EUGS is not a perfect strategy, nor should we compare it with the grand strategies of other single-state powers as it is a strategy of a collective actor. The strategies or white papers of countries focus on the external dimension of power projection, whereas one of the main functions of the collective endeavour is to bring more coherence between Member States regarding common threats, instruments at disposal, etc. Moreover, it will take time to accomplish the proposals set by the EUGS, as they will inevitably become an object of heated debates among the EU's Member States. However, as this paper shows, the seeds have been sown and the Union has made quite a significant step on its way to more strategic actorness.

Nevertheless, a few challenges should be taken into account and investigated further. First, the European Union has to deal with a multi-level system of strategies. The EUGS is not the only strategy produced by across the European Union. The majority of the Member States also have their national security strategies or white book processes. As Smith argued, all grand strategies are inherently competitive in nature $(2011,159)$; thus, there is a potential conflict between the Union's Global Strategy and grand strategies of the EU countries, in particular the big ones such as France or Spain. Hence, the interaction between different levels of strategic actorness within the EU is worth further exploration.

Secondly as Bretherton and Vogler claim, the Lisbon Treaty might have increased the EU's presence and capability, but because of changes in the external context, the opportunities for EU actorness have decreased (2013). Thus, external challenges and the global shift should be investigated as systemic variables that affect the Union's strategic actorness. In this context, putting forward research on 
external perceptions of the EU's willingness and ability to act as a strategic actor seems to be vital.

Thirdly and finally, the embeddedness of the EUGS in the regular policy process might pose a challenge. Perceiving the EUGS as a 'living' document with frequent and regular cycles of updating is not enough to guarantee its implementation. For that, it is necessary that the key decision-makers show their willingness by active engagement. As observers of the drafting process noted (Dijskra 2016; Sus 2016), there was only a little evidence of high policy level action during the outreach process, choosing instead to involve mid-range politicians and officials. If the translation of the vision put forward by the EUGS is to become a reality, then the Member States have to throw their full weight behind it. The dynamic developments on the field of security and defence allow for some optimism, but it would be helpful to investigate the levels of national action to implement the strategic project.

Since the economic crisis blew up, the EU found itself in a permanent crisis mode. Now it seems to be on the way to recovery-the three benchmarks of strategic actorness have been advanced and the table for more strategic actorness has been set. Now it is up to the national leaders to decide if they want to make use of the innovations and how sustainable these changes will be. There is a chance that the EU Member States, fearing marginalization in the world emerging powers in Asia and South America, will throw their weight of coherent political vision beyond EU's economic potential and mark their position in world affairs. However, it is important to perceive the advancement of European strategic actorness and its triedand-tested capability to join forces on high-stake issues and be able to influence world affairs as a long-term project. The danger of over-promising and underdelivering in terms of strategy is genuine (Toje 2008, 208).

Acknowledgements I wish to acknowledge the financial support of the National Research Council (along the project decision: DEC-2013/09/B/HS5/01356).

\section{References}

Aggestam, L. 2008. Introduction: Ethical power Europe? International Affairs 84: 1-11.

Allen, D., and M. Smith. 1990. Western Europe's presence in the contemporary international arena. Review of International Studies 16: 19-37.

Allen, D., and M. Smith. 2010. Strategic diplomacy in the European Union: Exploring relations with the BRIC countries, paper presented at the ECPR standing group on the European Union conference, Porto, 24-26 June 2010.

Bendiek, A., and H. Kramer. 2010. The EU as a 'strategic' international actor: Substantial and analytical ambiguities. European Foreign Affairs Review 4: 453-474.

Biscop, S. 2016 The EU global strategy: Realpolitik with European characteristics. Brussels: EGMONT Royal Institute for International Relations. Security Policy Brief no. 75.

Biscop, S. 2009. The value of power, the power of values: A call for an EU grand strategy. Brussels, Egmont. Egmont Paper no. 33. Edited volume.

Bretherton, C., and J. Vogler. 2006. The European Union as a global actor. London: Routledge.

Bretherton, C., and J. Vogler. 2013. A global actor past its peak? International Relations 27(3): 375-390.

Cooper, R. 2015. Evidence session No. 2. The United Kingdom Parliament, 10 September 2015. http:// data.parliament.uk/writtenevidence/committeeevidence.svc/evidencedocument/eu-external-affairssubcommittee/strategic-review-of-the-eus-foreign-and-security-policy/oral/21502.html. Accessed 10 October 2017. 
Cosgrove-Sacks, C., and K. Twitchett. 1970. New international actors: United Nations and the European economic community. London: Maximilian.

Council of the European Union. 2016. Implementation plan on security and defence, 14 November. https://eeas.europa.eu/sites/eeas/files/eugs_implementation_plan_st14392.en16_0.pdf. Accessed 2 Oct 2017.

Cross, M.D. 2011. Europe, a smart power? International Politics 48(6): 691-706.

Dijskra, H. 2016. Introduction: One-and-a-half cheers for the EU global strategy. Contemporary Security Policy 37(3): 369-373.

Drieskens, E. 2017. Golden or gilded jubilee? A research agenda for actorness. Journal of European Public Policy 24(10): 1534-1546.

EEAS. 2015. The European Union in a changing global environment. A more connected, contested and complex world. EU global strategy, 25 June. https:/europa.eu/globalstrategy/en/strategic-revieweuropean-union-changing-global-environment. Accessed 8 Oct 2017.

EEAS. 2016. Shared vision, common action: A stronger Europe. A global strategy for the European Union's foreign And security policy. Brussels, June.

EEAS. 2017a. From shared vision to common action: Implementing the EU global strategy. Year 1. https://europa.eu/globalstrategy/sites/globalstrategy/files/full_brochure_year_1.pdf. Accessed 8 Oct 2017.

EEAS. 2017b. Permanent structured cooperation-PESCO. Deepening defence cooperation among EU member states. Brussels: 19 October.

Engelbrekt, K., and J. Hallenberg. 2007. The European Union: A Strategic Actor under Permanent Construction? Paper prepared for the ECPR Standing Group Conference, Turin, 12-15 September.

EUISS. 2016. Towards an EU global strategy_Consulting the experts. Institute for Security Studies.

European Commission. 2016. European defence action plan. Brussels, 30 November.

European Commission. 2017a. White paper of the future of Europe. Reflections and scenarios for the EU27 by 2025. https://ec.europa.eu/commission/sites/beta-political/files/white_paper_on_the_ future_of_europe_en.pdf. Accessed 21 Oct.

European Commission. 2017b. Reflection paper on the future of European defence. https://ec.europa.eu/ commission/sites/beta-political/files/reflection-paper-defence_en.pdf. Accessed 21 October.

European Commission. 2017c. Press release. A European defence fund: $€ 5.5$ billion per year to boost Europe's defence capabilities, 7 June. http://europa.eu/rapid/press-release_IP-17-1508_en.htm. Accessed 1 Oct 2017.

European Commission Public Opinion. 2017. Public opinion and a common defence and security policy among Member States. http://ec.europa.eu/commfrontoffice/publicopinion/index.cfm/Chart/ getChart/chartType/lineChart/themeKy/29/groupKy/181/savFile/195. Accessed 25 Oct.

European Council. 2013. European council meeting-Conclusions. Brussels, 19-20 December.

European Council. 2015. European council meeting-Conclusions, Brussels, 26 June.

European Council. 2017. European council meeting-Conclusions, Brussels, 19 October.

Falkner, R. 2017. Rethinking Europe's external relations in an age of global turmoil: An introduction. International Politics 54(4): 389-404.

Hill, Ch. 1993. The Capability-Expectations Gap, or Conceptualizing Europe's International Role. Journal of Common Market Studies 31(3): 305-328.

Hoffmann, S. 2000. Towards a common foreign and security policy? Journal of International Affairs 38(2): 189-199.

Howorth, J. 2009. ESDP: Implementing a Grand Strategy. In What ambitions for European defence in 2020?, ed. A. De Vasconcelos. Paris: EUISS.

Howorth, J. 2010. The EU as a global actor: Grand strategy for a global grand bargain? Journal of Common Market Studies 48(3): 455-474.

Howorth, J. 2016. EU global strategy in a changing world: Brussels' approach to the emerging powers. Contemporary Security Policy 37(3): 389-401.

Hyde-Price, A. 2004. European security, strategic culture, and the use of force. European Security 13(4): 323-343.

Hyde-Price, A. 2006. Normative' power Europe: A realist critique. Journal of European Public Policy 13(2): 217-234.

Juncker, J.C. 2016. State of the Union 2016, 14 September 2016.

Juncker, J.C. 2017. State of the Union 2017, 13 September 2017. 
Junker, J.C. 2014. A new start for Europe: My agenda for jobs, growth, fairness and democratic change political guidelines for the next European Commission. https://ec.europa.eu/commission/sites/betapolitical/files/juncker-political-guidelines-speech_en.pdf. Accessed 1 Nov.

Jupille, J., and J.A. Caporaso. 1998. States, agency, and rules: the European Union in global environmental politics. In The European Union in the World Community, ed. C. Rhodes, 213-229. Boulder: Lynne Rienner.

Keating, D. 2015. Juncker calls for an EU army. European Voice, 3. September.

Koenig, N., and Hass, J. 2017. The EU as 3-D power: should Europe spend more on diplomacy, development and defence. Berlin: Jacque Delores Institute, Policy Paper no. 206.

Manners, I. 2002. Normative power Europe: A contradiction in terms? Journal of Common Market Studies 40(2): 235-258.

Marrone, A., Pirozzi, N., and Sartori, P. 2017. PESCO: An Ace in the hand for European Defence. Rome: IAI, 21 March.

Merlingen, M. 2012. The EU security policy. What it is, how it works, why it matters. Boulder: Lynne Rienner.

Mogherini, F. 2014. Answers to the European Parliament. Questionnaire to the commissioner-designate federica Mogherini high representative of the Union for foreign affairs and security policy vicepresident of the commission. http://www.europarl.europa.eu/hearings-2014/resources/questionsanswers/Hearings2014_Mogherini_Questionnaire_en.pdf. Accessed 4 October.

Mogherini, F. 2015. Preface. In Towards an EU global strategy-Background, process, references, ed. A. Missiroli. Paris: EUISS.

Moravcisk, A. 1999. A new statecraft? Supranational entrepreneurs and international cooperation. International Organization 53(2): 267-306.

Niemann, A., and C. Bretherton. 2013. EU external policy at the crossroads: The challenge of actorness and effectiveness. International Relations 27 (3): 261-275.

Novotna, T. 2017. The EU as a global actor: United we stand, divided we fall. Journal of Common Market Studies 55: 177-191.

Orbie, J. 2006. Civilian power Europe: Review of the original and current debates. Cooperation and Conflict 41(1): 123-128.

Pomorska, K., and S. Vanhoonacker. 2016. Europe as a global actor: Searching for a new strategic approach. Journal of Common Market Studies 54: 204-217.

Poushter, J., and D. Manevich. 2017. Globally, people point to ISIS and climate change as leading security threats. Concern about cyberattacks, world economy also widespread. Washington: Pew Research Center.

Sjöstedt, G. 1977. The external role of the European community. Farnborough: Saxon House.

Smith, M.E. 2011. A liberal grand strategy in a realist world? Power purpose and the EU's changing global role. Journal of European Public Polic 18(2): 144-163.

Smith, K. 2017. A European Union global strategy for a changing world? International Politics 54(4): 503-518.

Smith, M., and H. Xie. 2010. The European Union and China: The logics of "strategic partnership". Journal of Contemporary European Research 6(4): 432-448.

Sus, M. 2016. Member states as strategy-maker or strategy-taker? Analyzing polish involvement in the development of the EU global strategy. Polish Political Science Yearbook 45: 337-350.

Tocci, N. 2016. Interview with Nathalie Tocci on the global strategy for the European Union's foreign and security policy. The International Spectator 51(3): 1-8.

Tocci, N. 2017. From the European security strategy to the EU global strategy: Explaining the journey. International Politics 54(4): 487-502.

Toje, A. 2008. The European Union as a small power, or conceptualizing Europe's strategic actorness. Journal of European Integration 30(2): 199-215.

Von der Leyen, U. 2017. An ever closer military Union. Handelsblatt, 17 October. https://global. handelsblatt.com/opinion/an-ever-closer-military-union-eu-defense-european-union-germanyfrance-cooperation-von-der-leyen-nato-841045. Accessed 1 November. 